\title{
HHV8 and Kaposi's sarcoma: a time cohort study
}

Margaret M Kennedy, Sebastian B Lucas, Robin R Jones, David D Howells, Steve J Picton, Emma E Hanks, James O’D McGee, John J O'Leary

\begin{abstract}
Aims-The recent finding that human herpes virus 8 (HHV8) is found in the majority of Kaposi's sarcoma (KS) cases supports the epidemiological observation that the tumour may be caused by an infectious agent. This study aimed to address when and how HHV8 evolved. Methods-A cohort of African endemic KS (49 samples from 45 patients) and European KS (18 samples from 13 patients), spanning 27 years, was assessed for the presence of HHV8 by both standard solution phase polymerase chain reaction (PCR) and the newly described technique of TaqMan PCR.

Results-HHV8 was present in approximately $49 \%$ (24 of 49 tissue samples) of the African cases and in more than $90 \%$ (16 of 18 tissue samples) of the European cohort, in keeping with recent seroepidemiological data.

Conclusions-HHV8 is strongly linked to the development of KS; however, in some patients, other factors may operate. The utility and flexibility of TaqMan PCR in detecting low copy viral target in human tissues was demonstrated.

(F Clin Pathol: Mol Pathol 1997;50:96-100)
\end{abstract}

Keywords: human herpes virus 8; Kaposi's sarcoma; polymerase chain reaction; TaqMan PCR

Kaposi's sarcoma (KS) is a disease of uncertain histogenesis. While initially described in males of Eastern European Jewish and Mediterranean extraction (classic KS) the disease is now known to occur endemically in young African adult males and children. It is also seen in the context of immunosuppression (transplant associated) and HIV infection. Among the latter group, $\mathrm{KS}$ is an aggressive disease and serves as an AIDS defining illness. ${ }^{1}$ Epidemiological data indicate that in AIDS patients, KS is a disease largely confined to homosexual and

Accepted for publication 20 February 1997 bisexual males with low reported incidences in transfusion associated AIDS (3\%) and haemophiliacs $(1 \%){ }^{2}$ The cause of $\mathrm{KS}$ is unknown but the latter finding suggests that it may be caused by an infectious agent, possibly transmitted sexually. The most likely candidate is the newly described human herpes virus 8 (HHV8)-Kaposi's sarcoma associated herpes virus $(\mathrm{KSHV})^{3}$ - that appears to be associated with the vast majority of $\mathrm{KS}$ cases examined, including classic, African endemic, and AIDS associated forms. ${ }^{4-18}$

Viral genetic analysis revealed that HHV8 is a $\gamma$ herpes virus with sequence homology to two other lymphomagenic viruses, Epstein Barr virus, and herpes virus saimiri. It has been categorised as a Rhadinovirus and is the only known member of this group to infect humans. ${ }^{19}$ The mode of acquisition of the virus is not known. It has been documented in peripheral blood mononuclear cells ${ }^{20} 21$ and its presence in semen suggests that the agent may be transmitted sexually. ${ }^{22}{ }^{23}$ Seroepidemiological data indicate that HHV8 is not a ubiquitous infection, ${ }^{24-29}$ its distribution being largely restricted to high risk groups and inhabitants of endemic areas. Furthermore, there has been a dramatic increase in the incidence of KS with the advent of HIV infection, which raises the possibility that the two agents may be cotransmitted. How and when did HHV8 evolve? To help clarify this issue we investigated a cohort of African endemic KS (some originating in the 1960s) for the presence of HHV8 to determine whether there was a temporal association between HHV8 and KS.

\section{Materials and methods}

Forty nine KS samples (including 10 lymph nodes) were obtained from 45 Malawi patients. The material dated from 1968 to 1982 (table 1). The cohort comprised 38 males and five females, aged four weeks to 81 years. Clinical information was not available on two patients (one each from the 1970 and 1980 patient groups, respectively).

The tissue was paraffin wax embedded but the method of fixation was uncertain. None of the patients was HIV positive. Eighteen tissue samples from 13 cases of HIV positive European KS (eight males and five females) from the 1980s and 1990s were used as a control cohort.

SOLUTION PHASE PCR

Tissue ribbons $(50 \mu \mathrm{m})$ were cut into sterile Eppendorf tubes observing anticontaminating procedures. Sections were de-waxed and suspended in $200 \mu$ l proteinase $\mathrm{K}$ digestion buffer (100 mM NaCl, $10 \mathrm{mM}$ Tris, $25 \mathrm{mM}$ EDTA, $0.5 \%$ SDS $\mathrm{pH} 8.4$ ) containing $0.1 \mathrm{mg} / \mathrm{ml}$ of

\begin{tabular}{lllllll}
$1980-82$ & $\begin{array}{l}19 \text { specimens/ } \\
19 \text { patients }\end{array}$ & $\begin{array}{l}16 \mathrm{M} / 2 \mathrm{~F} \\
(2 \mathrm{children})\end{array}$ & $\begin{array}{l}\text { nodes } \\
19 \text { skin }\end{array}$ & $5+$ & $2+$ & $\begin{array}{l}1 \text { additional } \\
\text { case }+\end{array}$ \\
$1984-95^{\star}$ specimens/ & $8 \mathrm{M} / 5 \mathrm{~F}$ & $\begin{array}{l}11 \mathrm{skin} / \\
13 \text { patients }\end{array}$ & & $16+$ & $16+$ & $\begin{array}{l}14 / 14 \\
\text { including } 1 \\
\text { node/ } \\
6 \text { other sites }\end{array}$ \\
& & & & & $\begin{array}{l}\text { additional } \\
\text { case }+\end{array}$ \\
\hline
\end{tabular}

,+ HHV8 positive.

${ }^{\star}$ European HIV positive cases. 


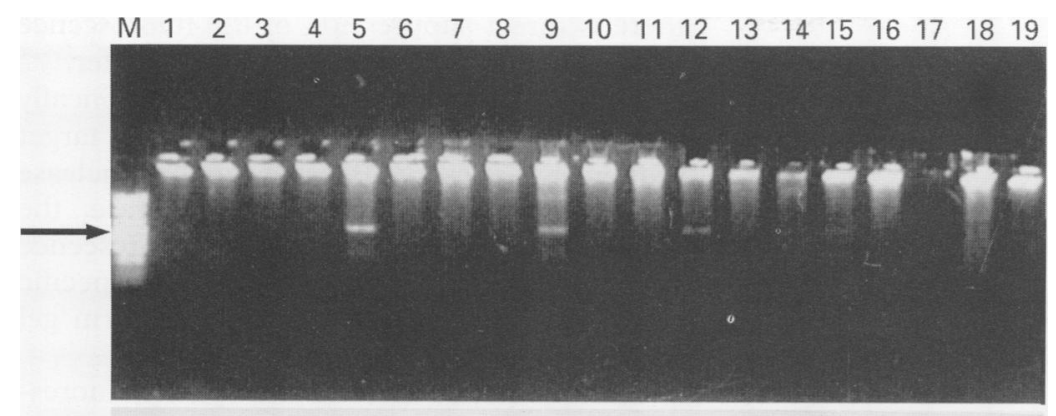

Figure 1 Gel electrophoresis showing HHV8 DNA amplicons (ORF 26) and confirmation by southern blotting.

proteinase $\mathrm{K}$, for three to five days at $37^{\circ} \mathrm{C}$ Subsequent phenol-chloroform extraction and precipitation with $3 \mathrm{M}$ sodium acetate/ethanol was performed. Samples were centrifuged and resuspended in high performance liquid chromatography (HPLC) water. The quality of extracted DNA was confirmed by $\beta$-globin amplification.

Nested primers amplifying the HHV8 open reading frame (ORF) 26 were employed:

outer primers-KS4 5'-AGCACTCGCAGGGCAGTACG-3', KS5 5'-GACTCTTCGCTGATGAACTGG-3';

inner primers-KS1 5'-AGCCGAAAGGATTCCACCAT-3', KS2 5'-TCCGTGTTGTCTACGTCCAG-3'.

The following reaction conditions were employed: $0.5 \mu \mathrm{M}$ each primer, $200 \mu \mathrm{M}$ dNTPs, $1.5 \mathrm{mM} \mathrm{MgCl}_{2}, 1 \times$ PCR buffer (Perkin Elmer) and 2.5 units Amplitaq DNA polymerase (Perkin Elmer). All reactions were performed in a 480 DNA thermal cycler (Perkin Elmer) with cycling parameters as follows:

outer set $-94^{\circ} \mathrm{C}$ for 45 seconds, $60^{\circ} \mathrm{C}$ for 30 seconds, $72^{\circ} \mathrm{C}$ for 45 seconds, for 25 cycles;

inner set $-94^{\circ} \mathrm{C}$ for 45 seconds, $55^{\circ} \mathrm{C}$ for 30 seconds, $72^{\circ} \mathrm{C}$ for 45 seconds, for 35 cycles.

A $94^{\circ} \mathrm{C} 30$ second "hot start" was employed during both steps. Reaction products were visualised on an ethidium bromide stained $2 \%$ agarose gel (Sigma) (fig 1).

Positive cases were subsequently reamplified with ORF 25 (HHV8 major capsid protein $)^{30}$ as follows:

outer set-5'-AGGCAACGTCAGATGTGAC-3', 5'-GAAATTACCCACGAGATCGA-3';

inner set-5'-CATGGGAGTACATTGTCAGGACCTC-3'， 5'-GGAATTATCTCGCAGGTTGCC-3'.

Cycling parameters were as follows:

outer primers $-94^{\circ} \mathrm{C}$ for 55 seconds, $55^{\circ} \mathrm{C}$ for

45 seconds, $72^{\circ} \mathrm{C}$ for 45 seconds, for 25 cycles; inner primers $-94^{\circ} \mathrm{C}$ for 55 seconds, $60^{\circ} \mathrm{C}$ for 45 seconds, $72^{\circ} \mathrm{C}$ for 45 seconds, for 35 cycles.
SOUTHERN BLOTTING

Following overnight transfer in $20 \times \mathrm{SSC}$ ( $3 \mathrm{M}$ $\mathrm{NaCl}, 0.3 \mathrm{M}$ sodium citrate $\mathrm{pH} 7.0$ ) the filter was baked at $80^{\circ} \mathrm{C}$ for two hours and pre-hybridised for one to two hours in $5 \times$ SSC, $1.0 \%$ blocking reagent (Boehringer Mannheim), $0.02 \%$ SDS, $0.1 \%$ sodium lauroylsarcosine, $100 \mu \mathrm{g} / \mathrm{ml}$ sheared herring sperm DNA.

The filter was subsequently hybridised overnight with a biotin-labelled oligonucleotide probe (5'-TGTTGGTGTACCACATCTACTCCAAAATAT-3'). The filter was recov-

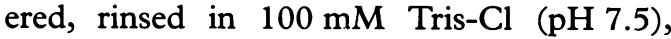
$150 \mathrm{mM} \mathrm{NaCl}$ at room temperature followed by two stringency washes at $50^{\circ} \mathrm{C}(2 \times \mathrm{SSC}$, $0.2 \%$ SDS). It was then placed for a further one to two hours in blocking solution at room temperature $(100 \mathrm{mM}$ Tris-Cl, $150 \mathrm{mM}$ $\mathrm{NaCl}, 1 \%$ blocking reagent (Boehringer Mannnheim); 0.5\% Tween 20).

Streptavidin-alkaline phosphatase (Gibco BRL) was applied for 10 minutes (concentra-

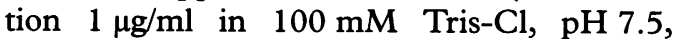
$150 \mathrm{mM} \mathrm{NaCl}$ ) followed by three washes in $100 \mathrm{mM}$ Tris-Cl, pH 7.5, $150 \mathrm{mM} \mathrm{NaCl}$, and a further rinse in $100 \mathrm{mM}$ Tris-Cl, pH 9.5, $100 \mathrm{mM} \mathrm{NaCl}, 50 \mathrm{mM} \mathrm{MgCl}$. The filter was finally covered by NBT/BCIP (nitroblue tetrazolium/5-bromo-4-chloro-3-indolyl phosphate) and chromagen colour development monitored.

\section{SEQUENCING}

Positive and negative strand sequencing was performed using the ABI PRISM 377 DNA sequencer and the ABI PRISM Dye Terminator Cycle Sequencing Core Kit, employing AmpliTaq DNA Polymerase FS, a genetically modified form of AmpliTaq DNA polymerase which reduces the concentration of dye labelled terminators in the sequencing reactions. Symmetric PCR product generated from ORF 26 of HHV8 was sequenced.

The PCR product was excised from a $2 \%$ agarose gel and purified using the Qiagen QIAquick protocol. Three volumes of buffer QX1 were added to the gel slice, incubated at $50^{\circ} \mathrm{C}$ for 10 minutes and $100 \mu \mathrm{l}$ of isopropanol was added to the $\operatorname{mix}(\mathrm{pH}>7.5)$. Following centrifugation, the flow through was discarded and $0.5 \mathrm{ml}$ of buffer QIAquick added to the column with further centrifugation. The sample was washed with $0.75 \mathrm{ml}$ of buffer PE, spun and $30 \mu \mathrm{l}$ of $10 \mathrm{mM}$ Tris- $\mathrm{HCl}, \mathrm{pH} 8.8$ or HPLC water was added. Following a final centrifugation step, the eluted DNA was stored.

Purified product (50-100 ng) was used for the cycle sequencing reaction. Cycling reagents were as follows: reaction premix, $8 \mu \mathrm{l}$ of $5 \times$ sequencing buffer, dNTPs, dye terminators, AmpliTaq DNA polymerase FS; template primer $3.2 \mathrm{pmol}$ (reaction volume $20 \mu \mathrm{l}$ ).

The following thermocycling parameters (25 cycles) were adopted:

rapid thermal ramp to $96^{\circ} \mathrm{C}-96^{\circ} \mathrm{C}$ for $10 \mathrm{sec}-$ onds;

rapid thermal ramp to $50^{\circ} \mathrm{C}-50^{\circ} \mathrm{C}$ for five seconds; 
TaqMan PCR
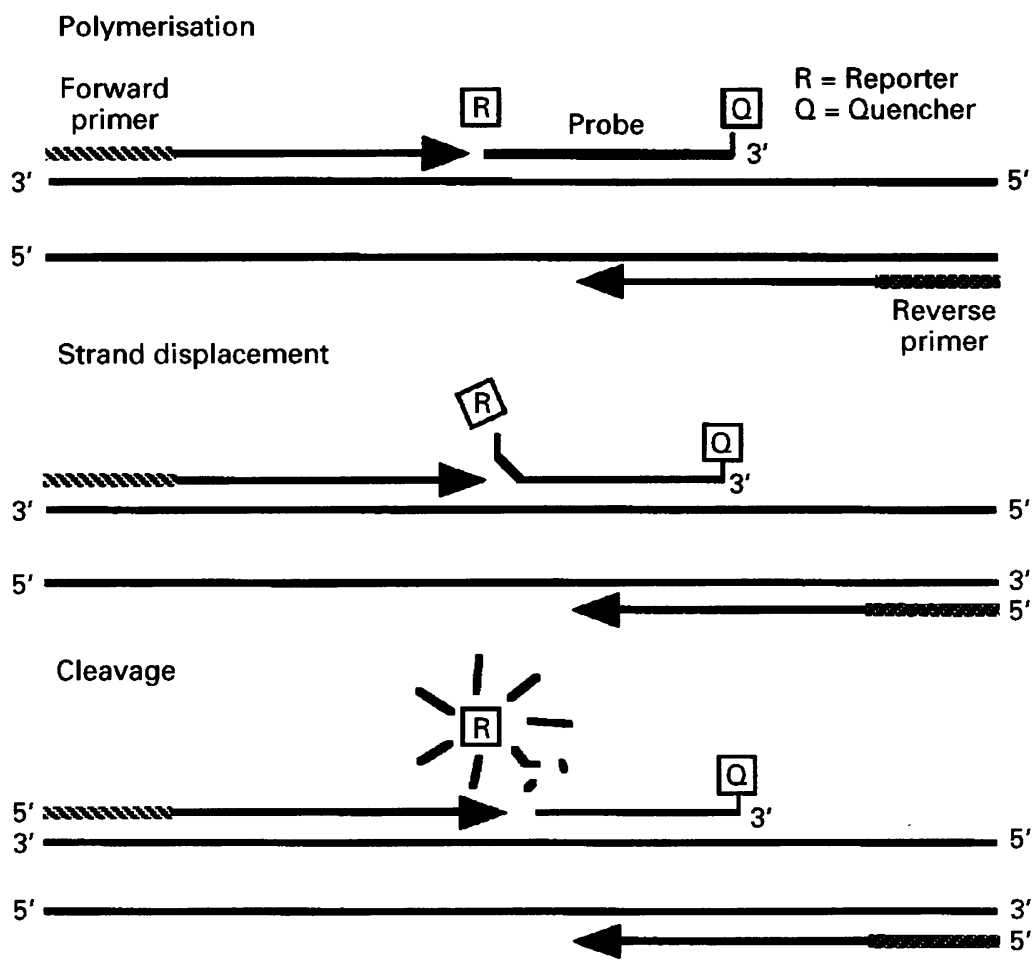

Polymerisation completed
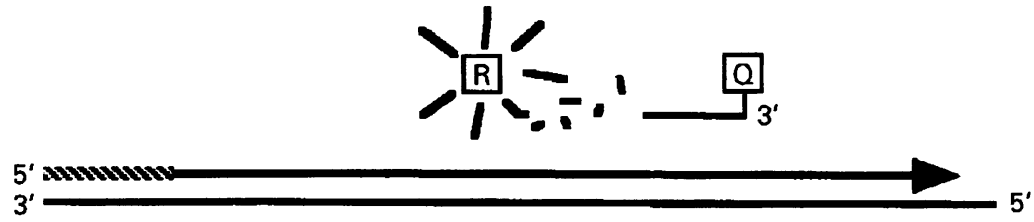

$5^{\prime}$

Figure 2 Schematic representation of TaqMan PCR, demonstrating the 5 ' nuclease dependent generation of reporter molecule $(R)$, which is target specific.

rapid thermal ramp to $60^{\circ} \mathrm{C}-60^{\circ} \mathrm{C}$ for four minutes.

All sequencing was performed on the Gene Amp PCR system 9600 (Perkin Elmer).

Following purification ( $3 \mathrm{M}$ sodium acetate/ $95 \%$ ethanol with a further rinse in $75 \%$ alcohol), the extension products were resuspended in HPLC water.

TAQMAN PCR

TaqMan PCR is a newly described technique which allows direct detection of PCR product by exploiting the 5' nuclease activity of AmpliTaq DNA polymerase $\mathrm{e}^{31-33}$ and the by the target specific release of a fluorescent reporter molecule during the PCR reaction (fig 2).

TaqMan PCR employs primer pairs as in conventional amplification as well as an oligonucleotide probe which consists of a fluorescent reporter dye (for example, FAM(6-carboxy-fluorescein)) at the $5^{\prime}$ end and a 3' quencher dye (for example, TAMRA(6-carboxy-tetramethyl-rhodamine).$^{34}$ When the probe is intact the proximity of the reporter dye to the quencher dye is such that there is direct suppression of the fluorescence of the latter by Forster-type energy transfer. ${ }^{35} 36$ During PCR, the probe will anneal specifically between the two primer pairs only if the target sequence is present. Because of the nuclease activity of AmpliTaq DNA polymerase, the probe is cleaved and reporter fluorescence released only if it is hybridised to its specific target. This obviates the need to perform gel analysis post-amplification.

The quantative increase in reporter fluorescence can be detected reliably using a luminescence spectrometer (for example, PerkinElmer LS-50B). The magnitude of the generated signal $(\triangle R Q)$ represents the difference between the sample $R Q(R Q+)$ and the no template control RQ (RQ-), where $\mathrm{RQ}=$ emission intensity of reporter divided by the emission intensity of quencher.

Using $\mathrm{T}$ distribution values ${ }^{37}$ it is possible to calculate a threshold $\Delta \mathrm{RQ}$ above which samples are recorded as positive. It is mandatory to include at least three no template controls per microtitre plate assay. The design of target specific primers and probe was dictated by the nearest neighbour method which calculates the optimal annealing temperature under defined solution phase kinetics. ${ }^{38}$

Extracted DNA was initially assessed by $\beta$ actin PCR using the following protocol: $1 \times$ PCR buffer II (Perkin Elmer), AmpErase UNG (Perkin Elmer) $0.01 \mathrm{U} / \mu \mathrm{l}, 4 \mathrm{mM} \mathrm{MgCl}{ }_{2}$, $200 \mu \mathrm{M}$ dNTPs, $300 \mathrm{nM}$ forward and reverse primers (forward 5'-TCACCCACACTGTGCCCATCTACGA-3', reverse 5'-CAGCGGAACCGCTCATTGCCAATGG-3'), and 200 nM TaqMan probe (5' F-ATGCCCTCCCCCATGCCATCCTGCGT-3' with the quencher TAMRA placed on base position 7 from the $5^{\prime}$ end).

Samples were subsequently amplified for HHV8 (ORF26) as follows: $300 \mathrm{nM}$ forward and reverse primers (KS1 5'-AGCCGAAAGGATTCCACCAT-3'; KS2 5'-TCCGTGTTGTCTACGTCCAG-3'), and $200 \mathrm{nM}$ TaqMan probe (5'F-CGCTATTCTGCAGCAGCTGTTGGTGTACCA-T-3', where $\mathrm{F}=\mathrm{FAM}$ and $\mathrm{T}=$ TAMRA). No template controls were performed in triplicate.

$\triangle R Q$ sample values were estimated on the LS50B luminescence spectrometer (Perkin Elmer).

\section{Results}

Twenty two samples demonstrated the characteristic 233 base pair amplicon of HHV8 (ORF 26) (fig 1). The product was confirmed on Southern blotting. An additional two cases were positive on TaqMan PCR (48.9\%) (table 1$)$.

Sixteen of the 18 European cohort amplified with both sets of primers with an additional case positive on TaqMan PCR (94\%). All positive cases were sequenced (submitted for publication).

Table 1 summarises the patient demographic details and illustrates the number of positive cases by solution phase and TaqMan PCR. In the 1960 cohort, 10 of 14 samples $(71.4 \%)$ were HHV8 positive. In the $1970-80$ group (predominantly lymph node specimens) eight 
of $16(50 \%)$ specimens were positive. A lower prevalence rate is reported in the $1980-82$ cohort (eight of 19) which may be a reflection of tissue fixation procedures rather than absence of HHV8 in the tissue. The 1984-95 group consisting of HIV positive European male and female KS cases shows that 16 of 18 specimens contained HHV8 DNA sequences. TaqMan PCR yielded additional cases in the 1970-80 and 1981-82 cohorts as well as in the European group. Globally the results are in keeping with that reported by others and illustrate that HHV8 is present in KS biopsy samples from the 1960s (pre-AIDS). It also clearly delineates that HHV8 is an independent factor in the pathogenesis of $\mathrm{KS}$, distinct from HIV.

\section{Discussion}

In recent years, much interest has focused on the pathogenesis of KS. Its cell of origin has been disputed as has the nature of the lesionthat is, whether it represents a true neoplasm. KS cell lines have been established which produce metastatic tumours in nude mice. ${ }^{39}$ Epidemiological data suggests an infectious aetiology ${ }^{2}$ and, as early as 1972, Giraldo et al documented the presence of herpes-type viral particles in KS cell cultures from different geographic regions. ${ }^{40}$ Many candidate infectious agents have been proposed including human papilloma virus and human herpes virus $6,,^{412}$ but none has been convincingly demonstrated. The recent discovery of a hitherto unknown herpes virus (HHV8) ${ }^{3}$ and its strong association with all forms of $\mathrm{KS},{ }^{4-18}$ suggests that we may at last have found the elusive agent.

However, the pathogenesis of $\mathrm{KS}$ is an extremely complex process which involves cell adhesion molecules, cytokines, and cellular genes. Many groups have examined the role of cytokines which probably act in both a paracrine and autocrine fashion, including platelet derived growth factor, interleukin-6, and basic fibroblast growth factor (bFGF). ${ }^{43-45}$ It has also been demonstrated that the HIV Tat protein induces angiogenic lesions in nude mice and acts synergistically with bFGF. ${ }^{46}$ Whether this is triggered by an infectious agent such as HHV8 has yet to be elucidated.

It has been documented that there is increased expression of the anti-apoptosis gene Bcl-2 in both spindle and endothelial cells of KS but not in normal blood vessels. ${ }^{47}$ Another group has shown that $\mathrm{Bcl}-\mathrm{X}_{\mathrm{L}}$, which also inhibits apoptosis, is expressed at a higher level than $\mathrm{Bcl}-2$ in $\mathrm{KS}^{48} \mathrm{CD} 40$ expression has also been shown to be upregulated. ${ }^{49}$ This signalling molecule is known to be involved with cell surface antigen expression, $B$ cell proliferation and differentiation, and inhibition of apoptosis. The Epstein Barr virus LMP-1 protein is known to enhance CD40 expression and it is possible that HHV8 may act in an analogous manner. ${ }^{50}$

The accumulating data on HHV8 suggests that it is likely to be involved in the pathogenesis of KS. It has been described in the majority of examined KS lesions, and seroepidemiological data indicate that HHV8 infection parallels that of KS prevalence. Viral gene expression patterns suggest that it is present in latent form within the majority of infected cells ${ }^{51}$ and its pattern of expression is unlike that of other related herpes viruses. However, its documentation in a rare body cavity-based lymphoma and Castleman's disease as well as in some non-HIV associated benign lymphoproliferative disorders ${ }^{52-54}$ does raise the possibility of it being a passenger virus. Alternatively, HHV8 may act as an oncogenic virus operating in disparate tumour and reactive conditions. It has also been described in transplant associated squamous carcinomas $^{55}$ even though this finding has been disputed by others. ${ }^{18} 30$

The results presented here are important in many respects: a unique cohort has been assembled from 1968-95; PCR amplification systems amplifying regions within ORF 25 and ORF 26 have been used; the newly developed technique of TaqMan PCR (with an estimated detection sensitivity of one to five viral copies in $10^{6}$ mammalian DNA sequences) has been employed; and the assembled patient groups revealed geographical differences, in that the 1968-82 group was from Malawi (Central Africa), the later group (1984-95) European.

The finding of $49 \%$ HHV8 positivity in the African population reflects the pattern of endemic KS in Africa. The data parallels seroepidemiological findings which have recently been published, documenting seroprevalence rates of approximately $50 \%$ in midAfrican locales. ${ }^{27}{ }^{29}$ The higher prevalence rates in male and female HIV positive European KS cases again reflects seroepidemiology data for such cohorts. ${ }^{24-29}$ Thus, there is overall agreement between serology and PCR data presented here, for the cohorts studied.

Our results suggest that HHV8 may not always be implicated in the pathobiology of $\mathrm{KS}$. It is possible that while the virus acts as an initiator in the inflammatory cascade, it may be lost as the lesion progresses. An additional consideration is that the virus may mutate over time with genetic divergence from currently known (published) sequences, and thus may not be amplified using current sequence primer designs. In any event, the exact mechanism of action of HHV8 in KS has not been fully elucidated. Clearly, the development of $\mathrm{KS}$ lesions is dependent on a complex interplay between inflammatory mediators and apoptosis genes with or without an initiating infectious agent. ${ }^{56}$

The authors thank the Malawi Ministry of Health.

1 Levine AM. AIDS-related malignancies: the emerging epidemic. F Natl Cancer Inst 1993;85:1382-97.

2 Beral,V. Epidemiology of Kaposi's sarcoma. Cancer Surv 1991;10:5-22

3 Chang Y, Cesarman E, Pessin MS, Lee F, Culpepper J, Knowles DM, et al. Identification of herpesvirus-like DNA sequences in AIDS-associated Kaposi's sarcoma. Science 1994;266:1865-9.

4 Ambroziak JA, Blackbourn DJ, Herndier BG, Glogau RG, Gullett JH, McDonald AR, et al. Herpes-like sequences in HIV-infected and uninfected Kaposi's sarcoma patients. Science 1995;268:582-3.

5 Moore PS, Chang Y. Detection of herpesvirus-like DNA sequences in Kaposi's sarcoma in patients with and those without HIV infection. N Engl F Med 1995;332:1181-5.

6 Huang YQ, Li JJ, Kaplan MH, Poiesz B, Katabira E, Zhang Huang YQ, Li JJ, Kaplan MH, Poiesz B, Katabira E, Zhang
WC, et al. Human herpesvirus-like nucleic acid in various forms of Kaposi's sarcoma. Lancet 1995;345:759-61.

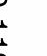

.


7 Dupin N, Grandadam M, Calvez V, Gorin I, Aubin JT, Havard S, et al. Herpesvirus-like DNA sequences in Havard S, et al. Herpesvirus-like DNA sequences in patients with

8 Su IJ, Hsu Y-S, Chang Y-C, Wang I-W. Herpesvirus-like DNA sequences in Kaposi's sarcoma from AIDS and nonAIDS patients in Taiwan. Lancet 1995;345:722-3.

9 Collandre H, Ferris S, Grau O, Montagnier L, Blanchard A. Kaposi's sarcoma and new herpesvirus [letter]. Lancet 1995;345:1043.

10 Boshoff C, Whitby D, Hatziioannou T, Fisher C, van der Walt J, Hatzakis A, et al. Kaposi's-sarcoma-associated herpesvirus in HIV-negative Kaposi's sarcoma. Lancet 1995; 345: $1043-4$

11 Lebbe C, de Cremoux P, Rybojad M, Costa da Cunha C, Morel P, Calvo F. Kaposi's sarcoma and new herpesvirus [letter]. Lancet 1995;345:1180.

12 Schalling M, Ekman M, Kaaya EE, Linde A, Biberfeld P. A role for a new herpes virus (KSHV) in different forms of Kaposi's sarcoma. Nature Med 1995;1:707-8

13 Rady PL, Yen A, Martin RW, Nedelcu I, Hughes TK, Tyring SK. Herpesvirus-like DNA sequences in classic Kaposi's sarcomas. 7 Med Virol 1995;47:179-83.

14 Noel JC. Kaposi's sarcoma and KSHV [letter]. Lancet 1995; 346: 1359.

15 Chang Y, Ziegler J, Wabinga $\mathrm{H}$, Katangole-Mbidde E, Boshoff C, Schulz T, ot al. Kaposi's sarcoma-associated herpesvirus and Kaposi's sarcoma in Africa. Arch Intern Med 1996;156:202-4

16 Jin Y-T, Tsai S-T, Yan J-J, Hsiao J-H, Lee Y-Y, Su I-J. Detection of Kaposi's sarcoma-associated herpesvirus-like DNA sequence in vascular lesions: a reliable diagnostic marker for Kaposi's sarcoma. Am f Clin Pathol 1996;105: 360-3.

17 Li JJ, Huang YQ, Cockerell CJ, Friedman-Kien AK. Localization of human herpes-like virus type 8 in vascular zation of human herpes-like virus type 8 in vascular
endothelial cells and perivascular spindle-shaped cells of endothelial cells and perivascular spindle-shaped cells of
Kaposi's sarcoma lesions by in situ hybridization. $A m \neq$ Kaposi's sarcoma lesions
Pathol 1996;148:1741-8.

8 Dictor M, Rambech E, Way D, Witte M, Bendsoe N. Human herpesvirus 8 (Kaposi's sarcoma associated herpesvirus) DNA in Kaposi's sarcoma lesions, AIDS Kaposi's sarcoma cell lines, endothelial Kaposi's sarcoma simulators, and the skin of immunosuppressed patients. Am f Pathol 1996;148:2009-16.

19 Moore PS, Gao S-J, Domingue\% G, Cesarman E, Lungu O, Knowles DM, et al. Primary characterization of a herpesKnowles DM, et al. Primary characterization of a herpesvirus agent

20 Whitby D, Howard MR, Tenant-Flowers M, Brink NS, Copas A, Boshoff C, et al. Detection of Kaposi sarcoma associated herpesvirus in peripheral blood of HIV-infected individuals and progression to Kaposi's sarcoma. Lancet 1995;346: 799-802.

21 Moore PS, Kingsley LA, Holmberg SD, Spira T, Gupta P, Hoover DR, et al. Kaposi's sarcoma-associated herpesvirus infection prior to onset of Kaposi's sarcoma. AIDS infection prior

22 Lin J-C, Lin S-C, Mar E-C, Pellett PE, Stamey FR, Stewart JA, et al. Is Kaposi's-sarcoma-associated herpesvirus detectable in semen of HIV-infected homosexual men? Lancet 1995;346:1601-2

23 Monini P, de Lellis L, Fabris M, Rigolin F, Cassai E. Kaposi's sarcoma-associated herpesvirus DNA sequences in prostate tissue and human semen. $N$ Engl F Med 1996;334: 1168-72.

24 Miller G, Rigsby MO, Heston L, Grogan E, Sun R, Metroka $C$, et al. Antibodies to butyrate-inducible antigens of Kaposi's sarcoma-associated herpesvirus in patients with HIV-1 si's sarcoma-associated herpesvirus in pation

25 Gao S-J, Kingsley L, Hoover DR, Spira TJ, Rinaldo CR, Saah A, ct al. Seroconversion to antibodies against Kaposi's sarcoma-associated herpesvirus-related latent nuclear antigens before the development of Kaposi's sarcoma. N Engl f Med 1996;335:233-41

26 Kedes DH, Operskalski E, Busch M, Kohn R, Flood J, Ganem D. The seroepidemiology of human herpesvirus 8 (Kaposi's sarcoma-associated herpes virus): distribution of infection in KS risk groups and evidence for sexual infection in KS risk groups and evidenc

27 Gao S-J, Kingsley L, Li M, Zheng W, Parravicini C, Ziegler $\mathrm{J}$, ct al. KSHV antibodies among Americans, Italians and Ugandans with and without Kaposi's sarcoma. Nature Med 1996;2:925-8

28 Lennette ET, Blackbourn DJ, Levy JA. Antibodies to human herpesvirus type 8 in the general population and in Kaposi's sarcoma patients. Lancet 1996;348:858-61

29 Simpson GR, Schulz TF, Whitby D, Cook PM, Boshoff C, Rainbow L, et al. Prevalence of Kaposi's sarcoma associated herpesvirus infection measured by antibodies to recombinant capsid protein and latent immunofluoresence antigen. Lancet 1996;348:1133-8

30 Boshoff C, Talbot S, Kennedy M, O'Leary J, Schulz T, Chang Y. HHV8 and skin cancers in immunosuppressed patients. Lancet 1996;347:338-9.

31 Lawyer FC, Stoffel S, Saiki RK, Myambo KB, Drummond $\mathrm{R}$, Gelfand DH. Isolation, characterization, and expression in Escherichia coli of the DNA polymerase gene from the extreme thermophile. Thermus aquaticus. of Biol Chem 1989;264:6427-37.

32 Holland PM, Abramson RD, Watson R, Gelfand DH Detection of specific polymerase chain reaction product by utilizing the $5^{\prime}$ to $3^{\prime}$ exonuclease activity of Thermus aquaticus DNA polymerase. Proc Natl Acad Sci 1991;88: $7276-80$.

33 Lyamichev V, Brow MAD, Dahlberg JE. Structure-specific endonucleolytic cleavage of nucleic acids by eubacterial DNA polymerases. Science 1993;260:778-83.

34 Lee LG, Connell CR, Bloch W. Allelic discrimination by nick-translation PCR with fluorogenic probes. Nucleic Acid. Res 1993;21:3761-6.

35 Forster $\mathrm{V}$ Th, Zwischenmolekulare Energie-Wanderung und Fluoreszenz. Ann Phlysics (Leipzig) 1948;2:55-75.

36 Lakowicz JR. Energy transfer. Principles of fluorescent spectroscopv. New York: Plenum Press, 1983:303-39.

37 Beyer WH, ed. CRC standard mathematical tables. 27 th ed Boca Raton: CRC Press, 1984

38 Rychlik W, Spencer WJ, Rhoads RE. Optimization of the annealing temperature for DNA amplification in vitro. Nucleic Acids Res 1990;18:6409 12.

39 Lunardi-Iskandar Y, Gill P, Lam VH, Zeman RA, Michaels F, Mann DL, et al. Isolation and characterization of an immortal neoplastic cell line (KS Y-1) from AIDSassociated Kaposi's sarcoma. I Natl Cancer Inst 1995;87: 974-81

40 Giraldo G, Beth E, Haguenau F. Herpes-type virus particles in tissue culture of Kaposi's sarcoma from differen geographic regions. 7 Natl Cancer Inst 1972;49:1509-26.

41 Huang YQ, Li JJ, Rush MG, Poiesz BJ, Nicolaides A, Jacobson M, et al. HPV-16-related DNA sequences in Kaposi's sarcoma. Lancet 1992;339:515-18.

42 Bovenzi P, Mirandola P, Secchiero P, Strumia R, Cassai E, Di Luca D. Human herpesvirus 6 (variant A) in Kaposi's sarcoma. Lancet 1993;341:1288-9.

43 Stürzl M, Roth WK, Brockmever NH, Zietz C, Speiser B, Hofschneider PH. Expression of platelet-derived growth factor and its receptor in AIDS-related Kaposi sarcoma in vivo suggests paracrine and autocrine mechanisms of tumour maintenance. Proc Natl Acad Sci USA 1992;89: 7046-50.

44 Miles SA, Rezai AR, Salazar-Gonzalez JF, Meyden MV Stevens RH, Logan DM, et al. AIDS Kaposi sarcomaderived cells produce and respond to interleukin 6. Proc Natl Acad Sii 1990;87:4068-72.

45 Ensoli B, Nakamura S, Salahuddin SZ, Biberfeld P, Larsson $\mathrm{L}$, Beaver B, et al. AIDS-Kaposi's sarcoma-derived cells express cytokines with autocrine and paracrine growth effects. Science 1989:243:223-6.

46 Ensoli B, Gendelman R, Markham P, Fiorelli V, Colombin $\mathrm{S}$, Raffeld M, et al. Synergy between basic fibroblast growth factor and HIV-1 tat protein in induction of Kaposi's sarcoma. Nature 1994;371:674-80.

47 Bohan-Morris C, Gendelman R, Marrogi AJ, Lu M Lockver JM, Alperin-Lea W, et al. Immunohistochemical detection of Bcl-2 in AIDS-associated and classical Kaposi's sarcoma. Am f Pathol 1996;148: 1055- 63.

48 Foreman KE, Wrone-Smith T, Boise LH, Thompson CB Polverini PJ, Simonian PL, et al. Kaposi's sarcoma tumor cells preferentially express Bcl-X ${ }_{1}$. Am F Pathol 1996;149 $795-803$.

49 Pammer J, Plettenberg A, Weninger W, Diller B, Mildner M Uthman A, et al. CD40 antigen is expressed by endothelial cells and tumor cells in Kaposi's sarcoma. Am F Pathol 1996;148:1387-96.

50 Nickoloff BJ, Foreman KE. Charting a new course through the chaos of KS (Kaposi's sarcoma). Am f Pathol 1996;148:1323-9.

51 Zhong W, Wang H, Herndier B, Ganem D. Restricted expression of Kaposi sarcoma-associated herpesvirus (human herpesvirus 8) genes in Kaposi's sarcoma. Proc Natl Acad Sci 1996;93:6641-6.

52 Cesarman E, Chang Y, Moore PS, Said JW, Knowles DM Kaposi's sarcoma-associated herpesvirus-like DNA sequences in AIDS-related body-cavity-based lymphomas. $N$ Engl F Med 1995;332:1186-91.

53 Soulier J, Grollet L, Oksenhendler E, Cacoub P, CazalsHatem D, Babinet P, it al. Kaposi's sarcoma-associated herpevirus-like DNA sequences in multicentric Castleherpevirus-like DNA sequences in mul

54 Luppi M, Barozzi P, Maiorana A, Artusi T, Trovato R, Marasca $\mathrm{R}$, et al. Human herpesvirus-8 DNA sequences in human immunodeficiency virus-negative angioimmunoblastic lymphadenopathy and benign lymphadenopath with giant germinal center hyperplasia and increased vascularity. Blood 1996;87:3903-9.

55 Rady PL, Yen A, Rollefson JL, Orengo I, Bruce S, Hughes TK, Tyring SK. Herpesvirus-like DNA sequences in nonKaposi's sarcoma skin lesions of transplant patients. Lancet 1995;345: 1339-40.

56 O'Leary JJ. Seeking the cause of Kaposi's sarcoma. Nature Med $1996 \cdot 2 \cdot 862-6$ 